\title{
Degradation and outflow rate of protein supplements in the rumen of dry and lactating ewes and goats
}

\author{
M. HADJIPANAYIOTOU, A. KOUMAS, E. GEORGHIADES, \\ D. HADJIDEMETRIOU
}

Agricultural Research Institute, Nicosia, Cyprus

\begin{abstract}
Six dry Chios ewes and 6 dry Damascus goats an average weight of 58.1 and $60.0 \mathrm{~kg}$, respectively were used in experiment 1 . Animals were fed $42.8 \mathrm{~g}$ feed DM $/ \mathrm{kg}{ }^{0.75}$ composed $(\mathrm{kg} /$ $\mathrm{kg}$ ) of $0.46 \mathrm{~kg}$ concentrate and $0.54 \mathrm{~kg}$ barley straw. In another experiment, 6 lactating Chios ewes and 6 lactating Damascus goats with an average live weight of 64 and $60 \mathrm{~kg}$, respectively were used. They were given 129.2 and $125.6 \mathrm{~g}$ feed $\mathrm{DM} / \mathrm{kg}^{0.75}$, respectively. The feed composed $(\mathrm{kg} / \mathrm{kg})$ of 0.71 concentrate, 0.17 barley hay and 0.12 lucerne hay. At the end of a 14 day adaptation period, each animal was dosed with 40 (expt. 1) or $50 \mathrm{~g}$ (expt. 2) of Cr-treated soybean meal. Rectal grab samples were then taken over a $90 \mathrm{~h}$ period at $6 \mathrm{~h}$ intervals starting $12 \mathrm{~h}$ after labelling. Soybean meal was treated with sodium dichromate as outlined by Elimam and Ørskov (1984, Anim. Prod., vol. 38, p. 45). Mean fractional outflow rate (\% per h) of Cr-treated soybean meal from the rumen was taken as the slope of the regression line calculated from the regression equation of natural log faecal $\mathrm{Cr}$ concentration and time. It was suggested that $\mathrm{Cr}$-treated particles behaved in a similar way to original ones. Treatment of soybean with $\mathrm{Cr}$ resulted in a decrease of $\mathrm{DM}$ losses from dacron bags incubated in the rumen of sheep and goats for $40 \mathrm{~h}$ (untreated 0.610 $v$ treated 0.089$)$. Outflow rate of small particles $(\%$ per $h)$ from the rumen of the two species was similar (dry ewes 5.4 , dry goats 5.7 ; lactating ewes 8.6, lactating goats 8.1). Higher outflow rates from the rumen of animals offered high rather than low roughage diets has been reported by some authors. Thus, the higher values obtained in lactating compared to dry animals should be associated with the level of intake.

In another experiment, the in situ degradation of fish meal (FM) and soybean meal (SBM) was measured in the rumen of 3 Chios ewes and 3 Damascus goats fed ad libitum on $200 \mathrm{~g}$ concentrate, $200 \mathrm{~g}$ lucerne hay and straw. Nylon bags were incubated for $2,6,16,24$ and $32 \mathrm{~h}$. There were no differences between ewes and goats for effective DM (EDM) and CP (ECP) degradability (degradability values at various incubation periods combined mathematically with outflow rates of small particles from the rumen) within supplements (outflow rate $5 \% / \mathrm{h}: \mathrm{SBM}$ EDM ewes 37, goats 39 ; ECP ewes 27 , goats 28 ; FM-EDM ewes 32, goats 37 ; ECP ewes 38 , goats $39 \%$ ).
\end{abstract}

Key words: Ewes, goats, outflow rate, degradability.

\section{Effect of protein source on performance of lactating Chios ewes and Damascus goats, and degradability of protected and unprotected soybean meal in the rumen of goats}

\author{
M. HADJIPANAYIOTOU, A. KOUMAS, E. GEORGHIADES \\ Agricultural Research Institute, Nicosia, Cyprus
}

Two trials, one involving 36 twin suckling Chios ewes and the other 32 twin suckling Damascus goats were conducted to study the effect of protein source (fish meal vs soybean meal) on preweaning milk yield and its composition and growth performance of offspring. Feed supply (kg/day) of ewes consisted of 2.36 concentrate, 0.41 lucerne hay $(247 \mathrm{~g} \mathrm{CP} / \mathrm{kg}$ DM) and 0.56 barley hay $(80 \mathrm{~g} \mathrm{CP} / \mathrm{kg} \mathrm{DM})$; the corresponding values for goats were $2.18,0.31$ and 0.61 , respectively. The concentrate mixtures were in pelleted form. The control $(\mathrm{C})$ concentrate mixture in both trials was composed $(\mathrm{kg} / \mathrm{t})$ of 736 barley grain, 195 soybean meal (SBM), 50 wheat bran, 5 dicalcium phosphate, 10 limestone and $4 \mathrm{NaCl}$. In the ewe trial, SBM was totally replaced by 
fishmeal (FM) (121 kg FM and $74 \mathrm{~kg}$ barley grain/t), whereas in the goat trial, FM mixture (FG) was composed $(\mathrm{kg} / \mathrm{t})$ of 769 barley grain, $112 \mathrm{SBM}, 50 \mathrm{FM}$, the other ingredients remaining the same as in the control mixture. CP (g/kg DM) content was 201, 194 and 199 for C, FE and FG mixtures, respectively. DM and CP degradation of the 3 concentrate mixtures were measured using nylon bags incubated in the rumen $(2,6,16,24$ and $32 \mathrm{~h})$ of 3 Damascus goats. There were no significant differences between mixtures for $\mathrm{DM}$ or $\mathrm{CP}$ effective (degradability values at various incubation periods combined mathematically with outflow rates $(5 \% / \mathrm{h})$ of small particles from the rumen) degradability values (C : DM 51.7, CP 45.0 ; FM : DM 50.8, CP 38.3, FG : DM 53.1, CP $46.4 \%)$.

Milk yield of ewes fed fish meal (FE) was significantly $(\mathrm{P}<0.05)$ higher than that of those fed the $\mathrm{C}$ diet (FE 3.84 vs C $3.44 \mathrm{~kg} /$ day). There were no difference between treatments in ewe milk fat (C 44 vs FE $43 \mathrm{~g} / \mathrm{kg}$ ) or protein content (C 54 vs FE $53 \mathrm{~g} / \mathrm{kg}$ ), whereas milk yield of goats was similar in the two treatments (C 3.87 vs FG $3.82 \mathrm{~kg} /$ day). However goats fed FM produced milk with a higher fat (C 32 vs FG $36 \mathrm{~g} / \mathrm{kg}$ ) and protein (C 38 vs FG $41 \mathrm{~g} / \mathrm{kg}$ ) content. Except a better conversion (milk/gain ratio) efficiency (C 5.17 vs FE 4.44) of male lambs of suckling ewes fed the fish meal diet, no other difference on the performances of lambs or kids was observed. Lambs consumed less milk than kids (Lambs: males 4.69 , females 5.13 ; kids : males 6.63 , females 6.98 ) per unit of bodyweight gain.

In another trial, different levels $(0,0.3,0.6$ or $0.9 \mathrm{~g} \mathrm{HCHO} / 100 \mathrm{~g} \mathrm{SBM})$ of $40 \%$ formaldehyde were used for treating SBM. Treated SBM was stored in sealed polyethylene bags for 1 or 5 days. Bags were then opened and treated SBM was laid onto a plastic sheet forming layers of $2.5 \mathrm{~cm}$ depth and left exposed for $72 \mathrm{~h}$. Treated and untreated SBM were incubated into the rumen of 3 Damascus goats for 8 and $24 \mathrm{~h}$ for determination of dry matter (DM) and crude protein (CP) disappearance (D). Increasing levels of HCHO reduced DM and CP D. Mean DM and $\mathrm{CP}$ disappearance of the two incubation periods was : control : 50.0, 32.2, 0.3 HCHO : 41.0, $14.5,0.6 \mathrm{HCHO}: 37.0,10.7 ; 0.9 \mathrm{HCHO}: 33.0,10.4 \%$. Storage period did not affect D, but both $D M$ and $C P$ were increased with prolonged incubation periods $(8 \mathrm{~h}: 34.5 ; 13.0 ; 24 \mathrm{~h}$ : $45.5 ; 21.6 \%)$.

Key words: Ewes, goats, protein source, formaldehyde treatment, milk yield.

\title{
Nitrogen flows in the gut of dairy goats: quantitative and qualitative aspects
}

\author{
F. LAURENT, G. BLANCHART, J. BRUN-BELLUT
}

E.N.S.A.I.A.-INRA, Sciences Animales, 2, avenue de la Forêt de Haye, 54500 Vandouvre (France)

Nitrogen flows were measured in the gut of two lactating goats $(2 \mathrm{~kg}$ milk per day) fitted with a simple rumen and a duodenal cannulas and housed in metabolic crates. They were fed ad libitum in two equal meals during 30 days for each diet. The diets consisted of green roughage (raygrass $=$ RGA) and concentrates or maize silage $(M)$ or a mixed diet (hay, dried beet pulps, concentrates $=$ HPC). The OM, CP and CF contents (\% DM) were 83.9, 92.8, 94.9 and 14.0, 12.0, 7.8 and 30.3, 24.5, 22.7 respectively for RGA, HPC and M diets. PDIN and PDIE values were 104 and 105,52 and 83,107 and $115 \mathrm{~g} / \mathrm{kg}$ DM respectively for RGA, M and HPC diets. Digesta flows were estimated on the $21^{\text {th }}$ day using PEG $(30 \mathrm{~g} /$ day $)$ and chromic oxyde $(2 \mathrm{~g} /$ day $)$ as markers. Microbial fraction was calculated after determining RNA level in duodenal digesta and NRNA/totalN ratio of bacteria isolated by differential centrifugation of duodenal content.

The amount of ingested dry matter was 1777,1538 , and $771 \mathrm{~g}$ respectively for HPC, RGA and $M$ diets. With HPC and RGA diets the amounts of ingested nitrogen ( 34.9 and $39.1 \mathrm{~g} /$ day) was higher than the nitrogen entering the duodenum (22 and $30 \mathrm{~g} / \mathrm{day})$. Net nitrogen recycling into the rumen seemed to be very important $(+15 \mathrm{~g} /$ day $)$ with $\mathbf{M}$ diet.

Microbial nitrogen/NAN ratio in the duodenum varied between $50 \%(\mathrm{M}), 68 \%(\mathrm{HPC})$ and $80 \%$ (RGA). The mean flow of NRNA $(2.4,2.3$, and $1.6 \mathrm{~g} /$ day) for HPC, RGA and $M$ was 1.8 fold higher than the ingested amount showing net synthesis of RNA in the rumen. Microbial efficiency synthesis ( $\mathrm{g}$ microbial $\mathrm{CP} / \mathrm{kg}$ DOM) varied between 109 for HPC, 159 for M, and 161 